\title{
THE QUEST FOR A FEDERAL WORKMEN'S COMPENSATION LAW FOR RAILROAD EMPLOYEES
}

\author{
Clarence A. Miller*
}

Any symposium relating to the Federal Employers' Liability Act should, it would seem, include a consideration of the efforts which have been made during the past forty years to obtain legislation which would extend to railroad employees and their dependents the benefits of workmen's compensation based on the liability of the employer regardless of fault. The following is an attempt to present a brief history of those efforts.

At common law an employer was under the duty to protect an employee from injury while he was engaged in the performance of the operations of his job. At the same time, the employee assumed the normal risks inherent in the line of work he engaged to perform. In order to protect the employee from the hazards of his work, the employer was required to exercise due care to provide a safe place in which to work, keep the work area in reasonable repair for normal use, and make inspections frequently enough to insure that proper working conditions were being maintained. The employer was required to provide safe tools and appliances for the employee to use. The employer had the duty to warn of danger, when he knew or discovered it, and to formulate, display, and enforce such rules and regulations as would afford employees obeying them a reasonable degree of protection while in the performance of their duties. The employer was also under the obligation to use reasonable care in the selection of competent fellow servants and to select them in numbers sufficient to insure the safe performance of all assigned tasks. These duties, being the sole responsibility of the employer, could not ordinarily be delegated to another. ${ }^{1}$

At common law, the liability of employers arises only where it can be shown that their negligence was the proximate cause of the injury or disability sustained by their employees. Thus, at common law, where an employer fails to take the foregoing described precautions, he has not acted as a reasonable and prudent man would have done under similar circumstances and would be considered negligent in exercising his duty toward his employees. Under the common law, injuries and fatalities could not be compensated through the courts unless it could be proved that the employer was negligent.

* LL.B. 1919, LL.M. I921, George Washington University. Vice President and Gencral Counsel, The American Short Line Railroad Association. Author, Legislative Evolution of the Interstate Commerce ACT (I930); I. C. C. Law and Procedure (1939). Contributor of many articles to legal publications. Member of the District of Columbia bar.

${ }^{1}$ Clark, The Legal Liability of Employers for Injuries to Their Employees, in the United States Bureau of Labor Statistics Bull. No. 74 3-19 (Igo8). 
The basis of any action under the FELA ${ }^{2}$ is negligence on the part of the railroad, so that there is no liability unless and until negligence is proved to the satisfaction of the jury. ${ }^{3}$ Workmen's compensation laws differ from the FELA in that the theory of a workmen's compensation law is that an employee is insured against the results of an injury received in the course of his employment, without reference to his contributory negligence, and without reference to common law liability. Workmen's compensation laws, being designed to give an injured worker prompt medical care and a reasonable part of the wages lost, at the expense of the employer, and to provide his dependents with reasonable sustenance during the loss of normal, expected wages, cover, in the majority of cases, the following fundamental points:

r. Provide certain, prompt and reasonable compensation to victims of work accidents and their dependents;

2. Free the courts from delay, cost, and the work load of mass personal injury litigation;

3. Relieve public and private charities of the financial drain caused by uncompensated industrial accidents;

4. Eliminate economic waste in payment of fees to lawyers and witnesses, and save the time ordinarily consumed by court trials and appeals;

5. Supplant concealment of fault in accidents by a frank study of causes, diminishing preventable accidents and reducing cost and suffering.

For many years the remedies for personal injuries of railroad employees engaged in interstate commerce were governed by the negligence laws of the various states. Congress, recognizing the difficulties under which railroad employees engaged in interstate commerce labored in obtaining redress for injuries, enacted the original Employers' Liability Act of June II, I906." This Act abolished the "fellow servant" rule and modified the "contributory negligence" rule. That law, by its terms, was applicable to all employees of railroads engaged in interstate commerce, without regard to whether or not the particular employee, at the time of injury, was engaged in interstate commerce. The law was held unconstitutional in Employers' Liability Act Cases, ${ }^{5}$ because, in the view of the Supreme Court of the United States, it transgressed upon powers reserved to the several states.

President Theodore Roosevelt, in a special message to the Congress, on January 3I, I908, said: ${ }^{6}$

The Supreme Court has decided the employers' liability law to be unconstitutional because its terms apply to employees engaged wholly in intrastate commerce as well as to employees engaged in interstate commerce. By a substantial majority the Court holds that the Congress had power to deal with the question in so far as interstate commerce is concerned.

As regards the employers' liability law, I advocate its immediate reenactment, limiting

235 STAT. 65 (Ig08), as amended, 45 U. S. C. $\$ \$ 5 I-60$ (1946).

${ }^{3}$ Urie v. Thompson, 337 U. S. 163 (I949).

34 STAT. 232 (rgo6).

${ }_{207}$ U. S. 463 (1908).

${ }^{4}$ Cong. Rec. 1347 (1908). 
its scope so that it shall apply only to the class of cases as to which the Court says it can constitutionally apply, but strengthening its provisions within this scope. Interstate employment being thus covered by an adequate national law, the field of intrastate employment will be left to the action of the several States. With this clear definition of responsibility the States will undoubtedly give to the performance of their duty within their field the consideration the importance of the subject demands.

Congress, accepting the recommendations of the President, re-enacted the Federal Employers' Liability Act on April 22, $1908^{7}$ and corrected the defect in the earlier law by expressly limiting its application to interstate railroad employees who, at the time of injury, were engaged in the interstate commerce business of the railroad. That law was amended by the Acts of April 5, 1910 ${ }^{8}$ and March 3, 1911, and, again on August II, 1939..$^{10}$

Under the Act of April 22, Ig08 it was generally supposed that the several states held concurrent jurisdiction with the Federal Government in applying the provisions of the law. Following a number of jurisdictional disputes in the courts, Congress clarified this aspect of the law by the amendment of April 5, 1910 ${ }^{11}$ which specified that the state courts would be vested with such concurrent jurisdiction.

The constitutionality of the Act of April 22, I908 ${ }^{12}$ was sustained in Second Employers' Liability Cases. ${ }^{13}$ With respect to the power of Congress, the Court said:

... it does not admit of doubt that ... Congress, in the exertion of its power over interstate commerce, may regulate the relations of common carriers by railroad and their employes, while both are engaged in such commerce, subject always to the limitations prescribed in the Constitution, and to the qualification that the particulars in which those relations are regulated must have a real or substantial connection with the interstate commerce in which the carriers and their employes are engaged.

Two years after the FELA of April 22, Ig08 was passed, Congress created an “Employers' Liability and Workmen's Compensation Commission," under the chairmanship of Senator Sutherland, and instructed it to study the whole problem of liberalizing statutory remedies for injured railroad employees. ${ }^{14}$ This commission has since been known as the "Sutherland Commission."

Early in its study the Sutherland Commission became convinced that the FELA did not offer the caliber of relief to which injured railroad employees (as covered by the law) were entitled, especially since the principles of workmen's compensation, as being studied by other states and commissions, offered a more equitable system of compensation for occupational injuries. The Sutherland Commission, therefore, directed its efforts primarily toward the possibility of developing an acceptable

35 STAт. 65 (I908), as amended, 45 U. S. C. \$\$5I-60 (1946).

836 STAT. 29 I (rgro), 45 U. S. C. $\$ 56$ (1946).

36 STAT. I167 (I9II), 45 U. S. C. $\$ 56$ (1946).

${ }^{10} 53$ STAT. 1404 (I939), 45 U. S. C. $\$ \$ 5 I-60$ (1946).

1136 Stat. 29 r (1910), 45 U. S. C. $\$ 56$ (1946).

1235 STAT. 65 (1908), as amended, 45 U. S. C. $\$ \$ 51-60$ (1946).

13223 U. S. I, 48-49 (1912).

1h Joint Resolution of Congress, approved June 25, I910, 36 Stat. 884. See I Sutherdand CommisMISSION REPORT II, infra, note I5. 
workmen's compensation law applicable to railroad employees. ${ }^{15}$ Among those who appeared before the Sutherland Commission in favor of a workmen's compensation law for interstate railroad employees was Mr. Miles M. Dawson, a New York attorney and consulting actuary, who had made studies abroad for the Russell Sage Foundation, and who later made studies for the United States Bureau of Labor Statistics on the subject of costs of employers' liability and workmen's compensation in foreign and American governments. ${ }^{16} \mathrm{Mr}$. Dawson asserted: ${ }^{17}$

Upon no theory can workmen's compensation ever be justified except upon the economic theory that the cost of all industrial accidents should enter into the price of the products and be paid by the consumers of the product, or into the price of the services and be paid by the consumers of the services.

The Sutherland Commission recommended a bill to provide an exclusive remedy and compensation for accidental injuries resulting in disability or death to employees of common carriers by railroad engaged in interstate or foreign commerce or in the District of Columbia. The bill worked out in detail a compensation for such injuries or death. Compensation was to be made in the form of annual payments for a number of years or for life. The fees to be paid to attorneys were to be specifically limited. The remedies were to be exclusive of any other remedies.

President Taft submitted the report of the Sutherland Commission to the Congress on February 20, IgI2, saying: $:^{18}$

I sincerely hope that this act will pass. I deem it one of the great steps of progress toward a satisfactory solution of an important phase of the controversies between employer and employees that has been proposed within the last two or three decades. The old rules of liability under the common law were adapted to a different age and condition and were evidently drawn by men imbued with the importance of preserving the employers from burdensome or unjust liability. It was treated as a personal matter of each employee, and the employer and the employee were put on a level of dealing, which, however it may have been in the past, certainly creates injustice to the employee under the present conditions.

The bill recommended by the Sutherland Commission was passed by the Senate and by the House, but in different language. It was then sent to conference committee so as to iron out the differences between the bill as passed by the Senate and as passed by the House. However, the bill never came out of conference committee because representatives of the railway labor unions could not agree on acceptable terms. $^{19}$

\footnotetext{
${ }^{25}$ The Report of the Sutherland Commission is entitled "Report of Commission to Investigate the Matter of Employers' Liability and Workmen's Compensation." It was published, in two volumes, as Sen. Doc. No. 338, 62d Cong., 2d Sess. (1912) [hereinafter Sutherland Commission Report].

${ }^{30}$ Cost of Employers' Liability and Workmen's Compensation Insurance, BUREAU of Labor Statistics BulL. No. $90749-83$ I (I9ro).

17 II Sutherland CoMmission Report 68.

${ }^{28} 48$ Cong. Rec. 2228 (I912); I Sutheriand Commission Report 7.

10 The history of that bill should be brielly recorded. After being favorably reported by the Senate Committee on the Judiciary ( 48 Cong. Rec. 4232, 4643 (1912); SEN. ReP. No. 553, 62d Cong., Ist Sess.), it was debated at length in the Senate, amended and passed on May 6, xgI2 by a vote of 64
} 
The causes of the disagreement among the railway labor unions which resulted in the defeat of the Sutherland bill are important. A number of young, totally disabled railroad employees had studied law and become members of the bar. Because of their railroad experience they gravitated to cases involving injured railroad employees. By remaining members of the railway labor organizations they frequently were selected as delegates to the annual conventions of those organizations. In those conventions, when questions about federal workmen's compensation laws were discussed, they would lead the attempt to defeat such proposals, and they exercised a very considerable amount of influence. ${ }^{20}$ These personal injury case lawyers, by obtaining occasional awards of substantial amounts of damage, were able to convince the railroad employees that the FELA was superior to any federal workmen's compensation law. Of course, the employees were not informed of the large number of cases in which no awards were obtained, or of the fact that in most cases of accident negligence of the railroad could not be shown. However, the employees preferred to gamble with damage suits rather than with the benefits of a federal workmen's compensation law. ${ }^{21}$

Litigation involving the question whether a particular employee was, at the time of injury, engaged in interstate commerce, was enormous, particularly in view of the fact that both federal and state courts could make the determinations. The problem of jurisdictional conflicts was reviewed in rgi7 by Professor Willard C. Fisher of New York University, who suggested that a federal workmen's compensation law, giving concurrent jurisdiction to the several states, might be a solution, although he favored complete coverage for all interstate commerce employees under a federal workmen's compensation law to be administered exclusively by the federal government. $^{22}$

On October 22-23, 1917, the Committee on Jurisdictional Conflicts of the International Association of Industrial Accident Boards and Commissions met with representatives of the railroads, the railway labor organizations, and the American Electric Railway Association for the purpose of determining the kind of a workmen's compensation law that would be most acceptable to the employees of carriers by railroad engaged in interstate commerce. As was to be expected, considerable

to I5 (48 CoNG. Rec. 5958-5959 (I912)). It was favorably reported by the House Committee on the Judiciary (49 Cong. Rec. 2580 (1913), H. R. Rep. No. 1441, 62d Cong., 2d Sess.), and passed by the House with amendments on March 1 , I913, by a vote of 218 to 81 (49 Conc. Rec. 4547 (1913)). A motion to concur in the House amendments was debated at length in the Senate (49 CoNG. REC. 4562$4563,4673-4675,4676-4677$ (1913)). The bill, however, was lost in the legislative rush on March 3 , 1913, because of lack of time for discussion of amendments before the closing of that session of Congress (49 Cong. Rec. 4677 (1913)).

${ }_{20}$ Bureau of Labor Statisttics Bull. No. 42 42-44 (I902).

${ }^{21}$ See Loree, Railway Employer Favors Workmen's Compensation, 23 Ax. LaB. Leg. Rev. 1 xo (1933); Clark, Workmten's Compensation and the Railroads: A Hesitating Revolution, 41 J. Polir. Econ. 806 (1933); Clark, Employees Engaged in Interstate and Foreign Commerce, 9 MonTHLy L^в. Rev, 294 (Nov. I919). The Monthly Labor Review is published by the U. S. Department of Labor, Burcau of Labor Statistics.

${ }_{22}^{2}$ Fisher, Some Defects and Suggested Changes in Workmen's Compensation Laws, in Proceedings of the Conference on Soctal Insurance, Bureau of Labor Statistics Bull. No. 212369 (1917). 
differences of opinion arose, particularly over the suggestion to draft a workmen's compensation law for operating employees. ${ }^{23}$ There was also opposition with respect to amending the FELA of Igo8 so as to give the operating employees the right to elect to sue for negligence under the FELA or to accept the benefits of the workmen's compensation laws of the state where the injury occurred. Among those dissatisfied with the suggestion was Colonel Alfred P. Thom, general counsel for the Railway Executives' Advisory Committee. However, it was decided to draft two bills, one for an amendment of the FELA of $x 908$, and the other a separate act to accomplish the same general result. It was also decided to gather additional information so as to determine just how many railway employees had no remedies for their injuries either under the FELA because the employer was not at fault, or under the workmen's compensation laws of the state where the injury occurred. ${ }^{24}$

Later, in I9I8, it was revealed that a "gentlemen's agreement" existed between an important railroad and its employees whereby the employees agreed not to sue for damages in cases where the possibility of proving negligence was admitted, the railroad agreeing that the injured employee would be paid compensation on the same basis as if he were covered by the compensation laws of the state in which the injury occurred. At that time less than half of the states granted benefits under their workmen's compensation laws sufficient to do little more than cover the total cost of hospital and surgical treatments. ${ }^{25}$

Jurisdictional conflicts were not the sole factors in influencing operating employees against workmen's compensation legislation. Two other factors were admittedly consequential. The first of these was the general unfamiliarity of the employees with the principles of workmen's compensation. The second was the vested interest of the lawyers for the railway labor organizations in the continuation of the liability system. These factors were stressed by a former member of the Sutherland Commission, then editor of The Railroad Trainman, in rgrg, when he advised the delegates to the Convention of Compensation Administrators of the attitude of the trainmen's unions toward workmen's compensation. He expressed the view that the operating employees did not understand what they were asking for when the Sutherland bill was proposed, and that they were easily influenced by their lawyers who presented a reasonable case against compensation loss. ${ }^{26}$

The following were among the arguments used to defeat the Sutherland bill:

$x$. The employees were denied the right to sue the employer, even when the employer was actually at fault, in consideration of being guaranteed a stated sum for each injury, regardless of who was at fault. The lawyers suggested that if the bill be passed, it should be made elective and not compulsory. In that event the em-

${ }^{23}$ Employees engaged in train and engine service, such as engineers, firemen, conductors, brakemen, switchmen, etc.

245 MONTHIY LAB. Rev. $152-157$ (Dec. 1917).

${ }_{25}$ Pillsbury, Conflicts Between Federal and State Jurisdictions in Accident Cases, Bureau of Labor Statistics BuzL. No. 248229 (19I9).

${ }^{20}$ Cease, Attitude of Railroad Transportion Organizations Toward Federal Compensation, 9 MonTHLY LAB. REV. 3 II (Nov. I9I9). 
ployee could then choose his remedy after the injury, so that in cases of negligence the lawyers would still be able to prosecute liability cases.

2. The compensation rate was based upon the normal daily wage instead of the monthly wage which was higher because it included overtime.

3. The accurate determination of wage loss in permanent partial disability is virtually impossible, and it would, therefore, be an injustice to delegate authority to any agency to fix payments based upon an observation of what a man might earn in another employment.

4. Men receiving compensation might be forced to work during strikes or lose their benefits.

5. The small fixed amounts for permanent partial disability were insignificant when compared with the substantial amounts awarded by juries in actions under the FELA.

6. At the expiration of compensation benefits, the employee would be worse off than before.

The position of the transportation organizations (operating employees) toward workmen's compensation legislation ranged from open and determined opposition to any form of federal workmen's compensation, ${ }^{27}$ to that of apparent indifference, ${ }^{28}$ to general support of the Sutherland bill.29

In 1920 , one workmen's compensation law administrator said: ${ }^{30}$

The Federal [Employers' Liability] Act, while admirable as an improved negligence statute, is, of course, wholly out of date at the present time, the States in their passage of workmen's compensation acts having far exceeded the relief afforded by the Federal Government by this statute. The great need now is to give railroad employees the same protection under workmen's compensation acts as employees in the more liberal States enjoy. This can be done either by the repeal of all Federal legislation on the subject, leaving railroad interstate employees to the protection of State laws, necessarily divergent, or by the enactment by Congress of a uniform Federal compensation act for railroad employees in interstate commerce.

Administrators of state workmen's compensation laws, who worked with the problems of compensating disabled employees on a day-to-day basis, became much concerned about the implications of jurisdictional conflicts.

In 1922, Samuel Gompers, as President of the American Federation of Labor, was authorized at the annual convention of the organization to establish a committee to study the status of the employer liability and workmen's compensation laws with reference, among other things, to conflicting interpretations of state and federal laws. That committee, consisting of Messrs. William Green, Frank Duffy, and

${ }^{27}$ Brotherhood of Railroad Trainmen.

${ }^{28}$ Brotherhood of Locomotive Firemen and Enginemen, and Order of Railway Conductors.

29 Brotherhood of Locomotive Engineers.

${ }^{30}$ French, The Trend of Workmen's Compensation-A Glance at Compensation History, Past and Present, if MoNTHLy Lab. Rev. I, 6 (Nov. 1920). 
Matthew Woll, reported to the I923 convention of the American Federation of Labor at Portland, Oregon, that: $:^{31}$

... the courts have held in construing the interstate commerce section of the Constitution of the United States, that persons employed by common carriers, engaged in transporting interstate commerce cannot come within the scope of or become subject to the operation of the State workmen's compensation laws.

Obviously the remedy for this state of affairs is the enactment of a federal workmen's compensation law applicable to those persons engaged in interstate commerce and who come wholly within the federal jurisdiction.

We believe such legislation should define clearly the class of employers and employees who are subject thereto and should be similar to the Ohio workmen's compensation law which the American Federation of Labor has officially accepted as the standard act in this character and kind of legislation.

During I924 there was a conference held with railroad representatives by a joint committee from the American Association for Labor Legislation and the International Association of Industrial Accident Boards and Commissions. That conference developed the fact that the operating railway labor organizations were still not in sufficient agreement to support a federal workmen's compensation law. ${ }^{32}$ The conference idea was not abandoned, and at the r925 meeting of the Compensation Administrators a motion was adopted to the effect that a committee of that association be appointed to confer with parties interested and take such steps as in its judgment might seem wise "in order to bring about a remedial condition for employees of railroad companies engaged in interstate commerce."33 At the 1926 meeting of the Compensation Administrators, the Committee on Compensation Legislation for Interstate Commerce Employees submitted a "progress report" revealing that opinion between railroad and harbor workers was then still divided as to the desirability of a uniform federal workers' compensation law.

The first industrial accident compensation laws were written upon the theory that both railroad workers and harbor workers would be included under state laws, since they were generally engaged in work presumably of a local nature, paid local taxes, owned local homes, and would become charges of local charities in cases where relief for disability was denied or discontinued. ${ }^{34}$ However, in New York Central R. R. v. Winfield, ${ }^{35}$ and Southern Pacific Company $v$. Jensen; ${ }^{36}$ it was held that neither interstate commerce workers nor maritime employees may come under the jurisdiction of state compensation laws if the work being performed at the moment of injury involved elements over which the federal government has exclusive jurisdiction. In the Winfield case it was held that the entire subject of the liability of interstate railway carriers for the death or injury of their employees while employed by them in interstate commerce is so completely covered by the provisions of the

\footnotetext{
${ }^{31}$ Report of the Proceedings of the Forty-Thro Annual Convention of the American FederaTION OF LABOR 76,78 (I923).

a2 Bureau of Labor Statistics Bull. No. 43244 (1926).

${ }^{33}$ Id. Bull. No. 406, at 150 .

${ }^{35} 244$ U. S. 147 (I9I7).

34 Id. Burt. No. 432 , at 43 .

${ }^{36} 244$ U. S. 205 (IgI7).
} 
FELA as to prevent any award under the New York Workmen's Compensation Act where an employee was injured or killed without fault on the part of the railway company while he was engaged in interstate commerce.

The Committee on Compensation Legislation for Interstate Commerce Employees, heretofore referred to, in its first "progress report," reviewed the many futile attempts previously made to push federal workmen's compensation bills through Congress, because of early adjournments or of irreconcilable differences between the two houses of the Congress. ${ }^{37}$

By 1928 the continued adamant opposition of certain railway labor organizations toward a federal workmen's compensation law made the situation so discouraging that the Commissioner of the Bureau of Labor Statistics suggested that the International Association of Industrial Accident Bureaus and Commissions drop the subject. ${ }^{38}$ However, in 1928 the Brotherhood of Locomotive Firemen and Enginemen appointed a special committee to study the problem of adapting the principle of workmen's compensation to injuries of trainmen. That committee reported that: $:^{30}$

Through adverse decisions of the courts, the present Federal Employers' Liability Act has been emasculated and it now affords relatively little relief to our injured members. While it is true that in comparatively few individual instances rather large sums are recovered as a result of verdicts secured through the courts, the fact remains that in a vast number of cases no relief is afforded through this medium. There are a number of reasons why our members are unable to take advantage of the present law in this respect, among them being $(\mathrm{r})$ lack of funds with which to carry on the required litigation; (2) fear of loss of position if court action is taken, etc. The situation as a whole seems to point to the necessity for a law that will more adequately and effectively take care of injured employees.

We respectfully recommend that the International President be authorized to take this matter up with the Railway Labor Executives' Association for the purpose of determining the advisability of securing a Federal Compensation Law applicable to men in interstate commerce, and for the further purpose of jointly instituting a movement, along with other interested organizations, for the purpose of securing a National Compensation Law that will effectively and adequately protect our injured members in interstate commerce.

Donald R. Richberg, for many years counsel for certain of the railway labor organizations, in an article entitled "Advantages of a Federal Compensation Act for Railway Employees," in I93x said:40

... the relief afforded by the Federal Liability Act is limited largely to those cases in which an employee is so severely injured that he is willing to gamble the cost of an expensive litigation; and is ready at the same time to abandon any future possibility of employment by the railroad.

Mr. Richberg then discussed briefly some of the advantages of a federal workmen's compensation law, and with particular respect to the railroad industry he

${ }^{37}$ Bureau of labor. Statistics Bull. No. 432, 49-50 (1926).

${ }^{38}$ Id. Bull. No. 456 , at I73 (1928).

1021 AM. LAB. Leg. Rev. 401 , 402 (I93I). 
said that such a system would tend to reduce strained employer-employee relations, virtually eliminate the expenses inherent in the litigation system, provide the employee with better and immediate medical care, hasten his return to a useful and efficient work status following temporary disability, and afford him a reasonable measure of protection in cases of total disability and occupational disease. ${ }^{41} \mathrm{Mr}$. Richberg suggested one of two laws might be passed-namely, (I) one to cover injured railway workers "when engaged in interstate commerce", or (2) the other to apply "at all times to all employees engaged in interstate commerce." $\mathrm{He}$ suggested the former only to insure its constitutionality, but he said that the latter would be much preferable because it would operate uniformly and eliminate any possibility of a twilight zone between state and federal jurisdiction.

The attitude of the majority of the trainmen toward a uniform federal workmen's compensation law remained unfavorable despite a steady increase in benefits under workmen's compensation laws which had been voted by several of the states. The rather liberal Longshoresmen's and Harbor Workers' Compensation Act of March 4, $1927^{42}$ had not changed their attitude. The prevailing attitude of the trainmen was explained to the International Association of Industrial Accident Boards and Commissions, in I93x by the then Secretary of Labor, Hon. W. N. Doak, in these words: ${ }^{43}$

The Brotherhood of Railroad Trainmen, whom I had the honor of representing as an officer for many years, has taken a consistent attitude in opposition to a workmen's compensation law since it was first presented to a convention of the Brotherhood more than eighteen years ago ... When it was proposed to abrogate the Federal employers' liability act and enact in its stead a national compensation measure, discussion among the railroad employees of all kinds in this country became active and occasionally vehement ... [the Sutherland bill] was favored, I believe, by a majority of the railroad brotherhoods, but opposed by the Brotherhood of Railroad Trainmen, with the result that it did not become a law.

Since the first action was taken by the convention of railroad trainmen, subsequent conventions of that organization have reaffirmed the opposition to workmen's compensation, and have actively opposed its enactment up to and including the last convention, which was held early this year.

After listing some eleven basic reasons for the opposition to workmen's compensation by the trainmen, Mr. Doak said: ${ }^{44}$

Therefore, unless and until radical reforms in systems already adopted are made, schedules more wisely increased, with the aim of affording redress of a more reasonable character to the men engaged in these hazardous occupations, I am seriously of the opinion that the railroad trainmen will oppose workmen's compensation as the sole and exclusive remedy.

The American Association for Labor Legislation disclosed that an agreement had

11 Id. at 403-404.

${ }^{23} 44$ STAT. $\mathrm{x424}$ (1927), 33 U. S. C. \$\$9oI et seq. (1946).

${ }^{4}$ The Attitude of the Railroad Brotherhoods Toward Workmen's Compensation and the Reason for Such Attitude, Bureau of Labor Statistrcs Burc. No. 56453 (1932).

"Id. at 57 . 
been signed on January 3 I, 1932 between representatives of the railway labor unions and the railroads containing a provision that some form of elective workmen's compensation would be stadied by a joint committee composed of representatives of several of the participating railroads and a committee appointed by the Railway Labor Executives' Association, with the understanding that the agreement for the study did not commit either party to accept or to await the results of the study. ${ }^{40}$

In March, 1932, Representative Swanson introduced H. R. I2170 (72nd Congress, 2d Session), providing that the FELA should not apply with respect to causes of action arising in any state, if, but for the enactment of such act, the provisions of the workmen's compensation law of such state would be applicable. This bill received no action by the Congress.

In June, I932, Senator Wagner introduced S. 4927 (72nd Congress, 2d Session) to provide compensation for disability and death resulting from injury to employees in interstate commerce. S. 1320 ( $73 \mathrm{~d}$ Congress, ist Session), and S. 3630 (73d Congress, Ist Session), also introduced by Senator Wagner, were substantially similar to S. 4927. As to these bills, Secretary Andrews of the American Association for Labor Legislation explained: $:^{48}$

In order that a concrete plan might be available for distribution and study, Senator Wagner, in June 1932, introduced in Congress the interstate compensation bill of the American Association for Labor Legislation, which was prepared in cooperation with compensation law administrators. Copies of this bill were widely distributed for criticism and suggestions. When revised the bill was reintroduced by Senator Wagner in February 1933, and again in April of that year. Under the auspices of the American Association for Labor Legislation, an all-day conference was held in November 1933, in which representatives of railroad carriers and railroad unions participated. At another all-day conference, arranged upon request of the railroad labor organizations, the bill was critically examined in every detail. With further revision, the bill was reintroduced in May $1934 . \ldots$

Senator Wagner requested the Federal Coordinator of Transportation to make a new study of the cause of railway accidents so that the most appropriate means of compensating injured employees of interstate carriers could be determined. A comprehensive survey was made by the Federal Coordinator of Transportation, the results being incorporated in his report entitled "Cost of Railroad Employee Accidents, I932."

This report showed that, for the year 1932 , there were 35,575 cases of injuries or deaths reported as closed out. Nearly one-half of these, or 16,876 , were closed in I932 without the employee, or his beneficiary in case of death, receiving any financial compensation. Of the 18,699 cases closed with payments, only 283 , or 1.5 per cent, were presented to the federal courts, resulting in judgments amounting to $\$ \mathrm{x}, 377,7 \mathrm{I} 7$, or II per cent of the total cost of $\$ 12,061,173$ for 1932 railroad accidents. This gave

422 AM. LAB. IEg. Rev. 57 (1932).

"Interstate Compensation for Transportation Workers, BUREAU of LABOR Standards BuLL. No. 4 (Discusston of Industrial Accidents and Diseases) 172 (1935).

${ }^{17}$ SEN. Doc. No. 68, 74th Cong., ist Sess. (1932). 
an average cost of $\$ 4,727$ per case decided by the courts. State compensation boards handled 3,868 cases, or 20.7 per cent of the total cases settled with payments, and awarded a total of $\$ 1,801,747$, or 14.9 per cent of the total cost for the year, the average award being $\$ 466$ per case. Settlements out of court accounted for 14,548 cases, or 77.8 per cent of the total cases settled with payments. The amount paid in settlements was $\$ 8,921,709$, or an average cost of $\$ 6 \mathrm{I}_{3}$ per case. When these figures are compared with those in the report of the Sutherland Commission covering the period rg08-rgro, it will be seen that while the number of accidents had decreased some 30 per cent, the cost had increased about 20 per cent. These increased costs, of course, reflected increases in payments for major injuries and death cases.

The figures produced by the report of the Federal Coordinator of Transportation indicated that railroad employees generally would receive better compensation under workmen's compensation laws than under the FELA. In the report, it is said that: ${ }^{48}$

The great majority of railroad-employee cases are settled without recourse to the courts, and the payments made are often less than similar awards under adequate workmen's compensation laws. As a result, the railroad-accident compensation system takes on many of the aspects of a lottery, from which a few employees draw large sums but from which many receive insufficient awards. It is this inequity which constitutes the greatest indictment of the system and furnishes the most powerful argument in favor of a reasonable Federal workmen's compensation law.

In introducing S. $x_{320}$ in the Senate on April I3, I933, Senator Wagner referred to the prior history of the Sutherland bill $:^{49}$

Twenty years ago a congressional committee reported voluminously in favor of a workman's compensation act for railway employees injured in interstate commerce. There was substantial agreement between railroad employers and railroad workers in favor of compensation legislation, but the official commission bill, although passed in modified form by both Houses of Congress, was permitted to die.

Speaking of the widespread acceptance of the principle of compensation, he went on to say: ${ }^{00}$

Meanwhile workmen's compensation has been almost universally adopted in this country to replace the antiquated system of employers' liability suits for damages. Interstate commerce employees comprise the most important group of workers remaining without this modern protection, which experience has demonstrated to be for the best interests of employers, employees, and the whole community.

After conferences with representatives of the United States Department of Labor and the Federal Coordinator of Transportation, Senator Wagner introduced, on June 25, r935, S. $3^{152}$ (74th Congress, First Session). At the time he introduced this bill he said: 51

The inadequacies and evils of the existing system of employers' liability for interstate commerce workers indicate the necessity for modern legislation to meet present-day needs

${ }^{48}$ Id. at 5-6.

${ }^{49} 77$ Cong. Rec. 1624 (1933).

${ }^{50}$ Ibid.

${ }^{51} 79$ CONG. REC. I0029-10030 (1935). 
which will effectively and adequately protect all interstate-commerce carriers' employees who are injured in the course of their employment. Such legislation can be worked out to the advantage of employers and employees and will at the same time relieve the public of the various expenses growing out of litigation.

A short while before that, in December I934, Mr. George M. Harrison, President of the Brotherhood of Railway and Steamship Clerks, and Acting Chairman of the Railway Labor Executives' Association, in an article entitled "Railway Labor Favors Federal Accident Compensation Law," tions constantly have taken the lead in pushing labor legislation through Congress, they have a very poor record with respect to getting a federal compensation law to protect the railway employees when injured while working in the line of duty. He said: ${ }^{53}$

The fault lies largely with railway employees themselves. ... There are still some railroad labor organizations that think an injured employee should have the right to make a choice as between compensation and the right to sue, but these organizations are in the minority.

Then, he said, "a very substantial majority of the unions [are] convinced of the advantages of a compensation act," and that for this reason he believed Congress would "enact such a measure without much delay."

In I935 the President's Committee on Economic Security recommended "passage of accident compensation acts for railroad employees." $" 54$

Mr. L. F. Loree, then President of the Delaware and Hudson Railroad Corporation, had, in I933, discussed the problem of many railroads with respect to the dual standard under which employees must be compensated for certain of their injuries. He had said: ${ }^{55}$

The same railroads that compensate their state employees in this manner [under State compensation laws] have, in cases of accidents to interstate employees, to meet highly organized attacks of attorneys who often make exorbitant profits from the exploitation of such accidents. The result is that, in these cases, the railroads pay much more than they should in justice be required to pay, while the injured employees and their dependents receive less than they would under the compensation laws of most states.

Mr. Loree indicated that the railroad industry was growing tired of this double standard of liability and promises, saying: ${ }^{50}$

... that if there were any genuine prospect of obtaining a suitable Federal statute of the same character there would be little, if any, opposition from railroad employers.

The first Railroad Retirement Act was held invalid by the Supreme Court of the United States on May 6, r935. The majority of the Court, speaking through Mr. Justice Roberts, said: ${ }^{57}$

\footnotetext{
${ }^{62} 24$ AM. LAB. LEG. REv. 16I (1934). ${ }^{53} I d$. at $161-163$.

5* RePORT to the PRESIDENT OF THE CoMMITTEe on Economic SECURITY 46 (1935).

${ }^{50}$ Railway Employer Favors Workmen's Compensation, 23 AM. LAB. LEG. REv. 110 (1933).

${ }^{\mathrm{EB}}$ Id. at IIX.

${ }^{87}$ Railroad Retirement Board v. Alton R. R., 295 U. S. 330, 370 (I935).
} 
That Congress may, under the commerce power, prescribe an uniform rule of liability and a remedy uniformly available to all those so engaged, is not open to doubt. The considerations upon which we have sustained compulsory workmen's compensation laws passed by the states in the sphere where their jurisdiction is exclusive apply with equal force in any sphere wherein Congress has been granted paramount authority. Such authority it may assert whenever its exercise is appropriate to the purpose of the grant. A case in point is the Longshoremen's and Harbor Workers' Compensation Act, passed pursuant to the delegation of admiralty jurisdiction to the United States. Modern industry, and this is particularly true of railroads, involves instrumentalities, tasks and dangers unknown when the doctrines of the common law as to negligence were developing. The resultant injuries to employees, impossible of prevention by the utmost care, may well demand new and different redress from that afforded in the past.

Taking cognizance of the argument that insuring risks tends to make an employer relax his vigilance over safety measures on the grounds that no matter what happens the insurance company will take care of it, the majority of the Court said: ${ }^{58}$

By the very certainty that compensation must be paid for every injury such legislation promotes and encourages precaution on the part of the employer against accident and tends to make transportation safer and more efficient. The power to prescribe an uniform rule for the transportation industry throughout the country justified the modification of common law rules by the Safety Appliance Acts and the Employers' Liability Acts applicable to interstate carriers, and would serve to sustain compensation acts of a broader scope, like those in force in many states.

Applying what the Court here said to the provisions of Senator Wagner's bill, one well-known writer reached the conclusion that the Supreme Court would sustain its enactment as a valid exercise of the power of Congress. ${ }^{59} \mathrm{He}$ specially pointed to this language of the majority opinion of the Court in the Alton case: ${ }^{\mathbf{6 0}}$

In dealing with the situation it is permissible to substitute . . . a fixed and reasonable compensation commuted to the degree of injury; to replace uncertainty and protracted litigation with certainty and celerity of payment; to eliminate waste; and to make the rule of compensation uniform throughout the field of interstate transportation, in contrast with inconsistent local systems.

In the dissenting opinon of Chief Justice Hughes in the Alton case, he said: ${ }^{.1}$

Interstate carriers cannot conduct their interstate operations without general officers and their staffs, without departments for major repairs and those for administering finances and keeping accounts. General management is as important to the interstate commerce of the carriers as is the immediate supervision of traffic, and the proper maintenance of equipment and the handling of moneys and the keeping of books are as necessary as the loading and moving of cars.

Senator Wagner continued to advocate his bill. In a paper submitted to the

${ }^{68}$ Id. at 370-371.

${ }^{60}$ Gellhorn, Federal Workmen's Compensation for Transportation Employees, 43 YAIE L. J. 906 (1934), and Validity of Federal Compensation for Transportation Employees, 25 AM. LAB. LEG. REV. 71,74 (1935).

${ }^{\circ 0}$ Railroad Retirement Board v. Alton R. R., 295 U. S. at 370.

${ }^{01}$ Id. at 389 . 
twenty-ninth annual meeting of the American Association for Labor Legislation, on December 28, I935, he said:62

It is strange that a protective movement like workmen's compensation, which gained such a headstart and received such widespread acceptance in this country, should not at once have sheltered the field of interstate transportation.

Commenting upon the fact that many railway employees "have been misled by the spectacular recoveries awarded in a few extraordinary court actions," he said that: $:^{63}$

... the focus of attention upon the rare case that an employee can take to court and win in court, obscures the all-important information about what is happening in the overwhelming majority of cases.

In the meantime, he had reintroduced his bill without being able to get any action on it. $^{64}$

In introducing S. 3152 in the Senate on June 25, I935, Senator Wagner quoted Chief Justice Taft in an address made by the latter on May 9, I932, before the American Law Institute: ${ }^{.5}$

A good many years ago it was attempted in Congress to provide a workmen's compensation act or what was equivalent to it, with reference to that great body of men whose lives are constantly at stake in the operation of the transportation systems We in the Supreme Court and all judges who have to do with the active conduct of litigation, realize the amount of time that is taken up in litigation of that kind, and also realize how much has been saved to the courts of the country by workmen's compensation acts. But we have no such system in the Federal Courts. We need it.

Senator Wagner also referred to the decision of the United States Supreme Court in Railroad Retirement Board v. Alton R. R., in which Mr. Justice Roberts pointed out the need of a compensation system for the railroad industry, and quoted $\mathrm{Mr}$. Justice Robert's opinion as follows: ${ }^{66}$

Every carrier owes to its employees certain duties the disregard of which render it liable at common law in an action sounding in tort. Each state has developed or adopted, as part of its jurisprudence, rules as to the employer's liability in particular circumstances. These are not the same in all the states. In the absence of a rule applicable to all engaged in interstate transportation the right of recovery for injury or death of an employee may vary depending upon the applicable state law. . . . Modern industry, and this is particularly true of railroads, involves instrumentalities, tasks and dangers unknown when the doctrines of the common law as to negligence were developing. The resultant injuries to employees, impossible of prevention by the utmost care, may well demand new and different redress from that afforded in the past. In dealing with the situation it is permissible to substitute a new remedy for the common law right of action; to deprive the

${ }^{82}$ Federal Workmen's Compensation for Transportation Workers, 26 AMr. LAB. LeG. REv. 15 (1936).

${ }^{\mathrm{B}}$ Id. at $\mathrm{I} 8$.

at S. 5695, 72d Cong., Ist Sess. (1933); see 76 Conc. Rec. 5069 (1933). S. 2793, 74th Cong., Ist. Sess. (1935); see 79 Cong. Rec. 7 r98 (1935).

o5 79 ConG. Rée. 10029-10030 (1935).

${ }^{80} 295$ U. S. 330 , at $369-37$ x. 
employer of common law defenses and substitute a fixed and reasonable compensation commuted to the degree of injury; to replace uncertainty and protracted litigation with certainty and celerity of payment; to eliminate waste; and to make the rule of compensation uniform throughout the field of interstate transportation, in contrast with inconsistent local systems. By the very certainty that compensation must be paid for every injury such legislation promotes and encourages precaution on the part of the employer against accident and tends to make transportation safer and more efficient. . . . Liability in tort is imposed without regard to such considerations; and in view of the risks of modern industry the substituted liability for compensation likewise disregards them. Workmen's compensation laws deal with existing rights and liabilities by readjusting old benefits and burdens incident to the relation of employer and employee. Before their adoption the employer was bound to provide a fund to answer the lawful claims of his employees; the change is merely in the required disbursement of that fund in consequence of the recognition that the industry should compensate for injuries occurring with or without fault.

\section{Senator Wagner continued $:^{\mathbf{6 7}}$}

From the general welfare angle, this problem has been discussed from time to time during the 23 years since Congress first attempted to pass legislation on the subject. At a joint meeting of representatives of railway operators and railway unions at Chicago in January, r932, steps were taken looking toward the earnest consideration of action by Congress on a Federal workmen's compensation law for employees of interstate common carriers. Looking toward more adequately meeting the hazard of industrial accidents, the Committee on Economic Security, in its report to the President on January I5th of this year, recommended that an accident compensation act for railroad employees be adopted.

After describing the administrative provisions of the bill, Senator Wagner continued: $:^{68}$

The inadequacies and evils of the existing system of employers' liability for interstate commerce workers indicate the necessity for modern legislation to meet present-day needs which will effectively and adequately protect all interstate-commerce carriers' employees who are injured in the course of their employment. Such legislation can be worked out to the advantage of employers and employees and will at the same time relieve the public of the various expenses growing out of litigation.

Despite all of Senator Wagner's efforts, however, no result ever came of them. None of the seven bills was ever reported out of committee. This failure was apparently due to a sharp difference of opinion on the bills.

Senator Wagner reintroduced his bill in the Seventy-Sixth Congress, on July 21, 1939, as S. $2862 .^{69}$ This bill was "to provide compensation for disability or death resulting from injury to employees of interstate carriers." In this bill most of the provisions of the New York State Workmen's Compensation Law were lifted bodily, or modified where necessary to accord with a nation-wide coverage and federal procedure. However, where there were provisions in the laws of some of the other states more favorable to the beneficiaries of such an act, they were substituted for the same provisions in the New York law or the other laws from which the bill was

or 79 Cong. Rec. ro030 (r935). ${ }^{68}$ Ibid.

${ }^{\text {co }}$ S. 2862, 76th Cong., Ist Sess. (1939); 84 CoNG. Rec. 9650 (1939). 
copied. This bill would, if enacted into law, have been administered by the Railroad Retirement Board.

By this time most of the operating railway labor organizations favored a federal workmen's compensation law "in principle." However, the Brotherhood of Railroad Trainmen continued to oppose this type of legislation, preferring to remain under the FELA, but with a broadening of that law. They maintained this position despite the fact that every study that had been made tended to show that workmen's compensation would be more beneficial to the majority of railroad employees than the FELA. Commenting upon this situation, The Railway Clerk, the official organ of the Brotherhood of Railway and Steamship Clerks, etc., in its issue for August I939, said : ${ }^{70}$

Nor can the failure to protect workers in interstate commerce be fairly laid at the door of Congress. As early as rgI2 a Federal law for the protection of workers in interstate commerce passed both Houses of Congress, but due to the failure of the railroad unions to energetically push for its passage, it perished because of a failure to iron out differences between the Senate and House bills. The passage of almost 30 years does not seem to have altered perceptibly the line-up at that time.

The trouble lies in the inability of the railroad unions to get together on a program. Although 19 of 2 I railroad unions have approved passage of workmen's compensation laws, and the other two have approved such bills in principle, the fact remains that almost three decades have gone by without any action to protect transportation workers against accidents falling under such laws.

Those who favor retention of the present Federal Employers' Liability Act have been deluded by the ease of securing jury verdicts for large amounts in damages in the lower courts, for a case is hardly ever decided against an employee. But this advantage is counterbalanced by the disposition of the appellate courts to reverse these verdicts. The higher up an employeee claim for damages goes in the judicial hierarchy, the more sacred become property rights and the less the value attached to human rights. The employee hardly ever won.

A compensation law would level off some of the big judgments. There is no doubt about that. But it would also remove the gamble railroad employees must now take in securing a big judgment or none at all. Instead of the long chance of winning a jackpot with the dice loaded against them, compensation for injuries and death would be reasonably certain under a Federal compensation law.

On August II, I939 the President signed into law S. I708 (76th Congress, First Session), amending the FELA, viz.: ${ }^{71}$

x. The provisions of the Act were extended to employees of carriers "any part of whose duties as such employees shall be the furtherance of interstate or foreign commerce; or shall, in any way directly or closely and substantially, affect such commerce."

2. Employees are not to be held to have assumed the risks of their employment where injury or death results in whole or in part from the negligence of the carrier.

3. Actions under the act are required to be commenced within three years from the day the cause of action occurred.

${ }^{70} 38$ THe RaIlway CleRK 329 (r939).

${ }^{71}{ }_{53}$ STAT. I $404_{4}$ (I939), 45 U. S. C. $\$ \$ 5 \mathrm{I}-60$ (I946). 
4. Any contract, rule, regulation or device whatsoever, the purpose, intent, or effect of which is to prevent employees of common carriers from furnishing voluntary information to a person in interest as to the facts incident to the injury or death of any employees, is declared void, and carriers are prohibited from disciplining employees who furnish such information.

Prior to the amendment of August II, I939, in order that there might be recovery under the FELA the injured or deceased employee must have been engaged in an "act of interstate transportation" at the time the accident occurred. It will readily be observed that the scope of the act was much broadened by the I939 amendment. However, at least the Brotherhood of Locomotive Firemen and Enginemen was not satisfied with the amended law. The president of that organization, on July 7, r94I, said: :2 $^{2}$

The Employers' Liability 'Act for the past twenty years has gradually been taking on new form, and if you asked a damage-suit lawyer what the act meant he would tell you that it means just what the courts say it means. You could no longer read the act and understand just what your rights were.

In 1944, the United States Employees' Compensation Commission appealed to Congress for a compensation law covering interstate employees. ${ }^{\mathbf{7 3}}$

On June I, I940, July I9, I94I, August 7, I94I and September 6, I94I, drafts of a proposed Interstate Workmen's Compensation Act were released by the Railroad Retirement Board, or as confidential committee prints of the Senate Committee on Interstate Commerce. No action was taken on any of these, because of the fact that the emphasis was shifted, resulting in extensive amendment of the Railroad Retirement Act and the Railroad Unemployment Insurance Act by Public Law 572 (79th Congress, 2d Session), which became effective, generally speaking, on July 31, $1946^{74}$ These drafts presumably give a reasonably clear preview of what might be expected in any federal workmen's compensation law, except that it is not possible, of course, to forecast how greatly these provisions will be "liberalized."

Section 20 of the Merchant Marine Act of $1915^{75}$ as amended by the Jones Act of $1920^{76}$ makes the provisions of the FELA available to seamen as an optional rem-

73 II I Brotherhood of Locomotive Fireman and Engineman's Magazine 98 (I94I).

${ }^{73}$ Twenty-Eighth Annual Report of the U. S. EMployees' Compensation Commission 4 (I944).

${ }^{24}$ The Railroad Social Insurance Bill was introduced in the House on May 15, 1944, by Representative Crosser as H. R. 4805 (78th Cong., 2d Sess. (1944); 9o Cong. Rec. 4525 (I944)), and in the Senate on May II, I944, by Senators Wagner and Wheeler as S. I9II (78th Cong., 2d Sess. (1944); 90 Cong. Rec. 4295 (1944)). Both bills, however, omitted Title III of the Committee Print which was the title covering workmen's compensation. Later in the Session, Representative Crosser substituted H. R. 5625 for H. R. 4805 (78th Cong., 2d Sess. (1944); 90 CoNG. REc. 9624 (1944)), but neither the House nor the Senate enacted this legislation during the Seventy-eighth Congress. The bills were again introduced in the Seventy-ninth Congress, and again without the compensation features, as H. R. I362 (79th Cong., Ist Sess. (1944); 91 Cong. Rec. 229 (1944)) in the House and S. 293 (79th Cong., Ist Sess. (1944); 9 I CoNG. REC. 23 I (1944)) in the Senate. H. R. 1362, as amended, was passed by both Houses and approved by the President on July 31, 1946, but without the workmen's compensation provisions (79th Cong., 2d Sess. (1946); 92 Cong. REc. IoI72, I0317-10322, 10636 (1946); 60 STAT. 722 (1946), 45 U. S. C. $\$ \$ 228 \mathrm{~A}-\mathrm{K}, 35 \mathrm{I}-363 \mathrm{~A}(1946))$.

${ }_{75}{ }_{38}$ STAT. II85 (I9I5), 46 U. S. C. $\$ 688$ (I946).

$7 a$ II STAT. 998, 1007, 46 U. S. C. $\$ 688$ et seq. (1946). 
edy against negligent ship owners. Seamen have long opposed workmen's compensation laws, so that it is likely that they would oppose the substitution of a federal workmen's compensation law for the FELA.

The American Bar Association proposes that the FELA shall not apply with respect to injuries suffered, or death resulting therefrom when occurring in any state, territory, or the District of Columbia, having a workmen's compensation act aplicable to such injury or death. At the seventy-second annual meeting of the American Bar Association, in St. Louis, Missouri, September 5-9, 1949, a resolution to that effect was adopted by the House of Delegates. ${ }^{77}$ As yet, no bill has been introduced in Congress to this effect. What position the interested parties will take in the event such a bill is introduced in Congress remains to be seen.

Each of the forty-eight states now has a workmen's compensation law. The extent to which railroads and their employees are subject to these laws is not susceptible of exact determination. The legislatures of forty-four states met during the year 1949 and enacted measures to "improve" their workmen's compensation laws. Most of them liberalized the benefits, and, in many instances, the benefits were increased substantially. During that year the benefits under the Federal Employee's Compensation Act were also liberalized. In addition to the liberalization of benefits, the state legislation for 1949 was outstanding for the trend toward full coverage of occupational diseases instead of schedule coverage. For instance, South Carolina enacted occupational disease coverage for the first time and adopted the all-inclusive type of law. Now, more than half of the forty states with occupational disease provisions have full coverage. Other amendments in 1949 included extension of coverage, reduction of waiting period, more liberal benefits, increased allowances for burial expenses, second-injury fund and vocational rehabilitation provisions, not to mention procedural changes. ${ }^{78}$

Some of the states have "elective" laws, under which employers may refuse to operate under the compensation act if they prefer to risk an injured worker's suit for damages. So far as can be ascertained, twenty-six states have elective laws and twenty-two have compulsory statutes which require every employer within the scope of the compensation act to accept that act and pay the compensation specified.

In eleven states ${ }^{79}$ the compensation laws apply mainly to listed "hazardous" or "extra-hazardous" employments. Illustrative of the complications which arise in endeavoring to interpret or apply compensation laws is the provision of the Maryland $\mathrm{law}^{80}$ which lists "extra hazardous" employments that are covered and then, in addition, provides that the act shall apply "to all extra-hazardous employments not specifically enumerated and to all work of an extra-hazardous nature." This

${ }^{77} 74$ A. B. A. REP. 108-109 (1949).

${ }^{28}$ Workmen's Compensation Legislation in 1949, 69 Monthly LaB. Rev. 514 (Nov. 1949).

${ }^{70}$ Illinois, Kansas, Louisiana, Maryland, Montana, New Mexico, New York, Oklahoma, Oregon, Washington, and Wyoming.

${ }^{80}$ MD. Code ANN., Vol. 2, Art. Ior, \$\$I4, 45, 67 (1939). 
illustrates that some of the state workmen's compensation laws are no more "certain" than is the FELA.

The power of a state to enact workmen's compensation laws, including the power to do away with the fellow servant rule and the assumption of risk doctrine as to employees engaged at the time of the accident in a service not coming within the provisions of the FELA, was sustained in Boston \& Maine R. R. v. Armburg, ${ }^{81}$ based upon many previous decisions of the Supreme Court of the United States.

It would seem to be possible, constitutionally, to repeal the FELA and to substitute therefor a federal workmen's compensation act, or alternatively, to make the provisions of the state workmen's compensation laws applicable to railroad employee injuries, if either would be desirable. This was considered constitutionally possible even before the Alton case was decided. ${ }^{82}$ It would also seem to be possible, constitutionally, to broaden the provisions of the Longshoremen's and Harbor Workers' Compensation Act, so as to make that law applicable to railroad employees. ${ }^{83}$

The Supreme Court of the United States is now much more "liberal" than when the Alton case was decided, so that constitutional impediments have very largely evanesced. The constitutional problems having vanished, the real issues are whether or not such legislation is desirable and whether it is possible to obtain it in view of the positions maintained by some of the organizations of employees.

81285 U. S. 234 (1932).

82 Albertsworth and Cilella, $A$ Proposed "New Deal" for Interstate Railway Industrial Harms, 28 I... L. REv. 587, 774, 785-786 (I934).

${ }^{83}$ See Andrews, Complete the Circle of Compensation, 15 Ax. LAB. Leg. REv. 285-288 (I925). 